\title{
An Econometric Analysis Of Two Possible Land Reform Strategies In Nigeria
}

Matthew N. Uwakonye, (E-mail: m_uwakonye@yahoo.com), Grambling State University Gbolahan S. Osho, (E-mail: oshogs@tsu.edu), Texas Southern University

\begin{abstract}
Land reform is concerned with changing the institutional structure governing man's relationship with the land, involving intervention in the prevailing pattern of land ownership, control and usage in order to change the structure of holdings, improve land productivity and broaden the distribution of benefits. Land reform is an aggregate of ideas and courses of action designed to resolve tenure problems. Nigeria is, an agrarian nation with over $56.8 \%$ of her working force engaged in farming. Doner and Kanel emphasize the significant contribution of the agricultural sector towards the overall economic development of underdeveloped countries, such as Nigeria where more than. 50\% of the working population is engaged in farming. Agricultural reforms has the advantage of provision of more employment, more equitable income distribution, a wider relevant structure for the growing manufacturing sector, a better base for farm financed welfare, and more rational investment policies in both the agricultural and nonagricultural sectors of the economy. Traditional land tenure system defined the opportunity to earn income in farming and provided the security that an individual would always have access to some part of his family's land. However, investment in land improvement and increases in productivity are hindered by tenure rules. The unknown nature of the ultimate results of tenure changes increases the risks involved in initiating any program of land reform.
\end{abstract}

\section{INTRODUCTION}

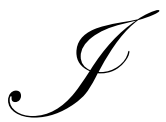

$\mathrm{n}$ the words of the World Bank, land reform is "concerned with changing the institutional structure governing man's relationship with the land, involving intervention in the prevailing pattern of land ownership, control and usage in order to change the structure of holdings, improve land productivity and broaden the distribution of benefits" (World Bank, 1996). Parsons (1996) defines land reform as the aggregate of ideas and courses of action designed to resolve tenure problems. His viewpoint is generally in line with the one expressed by the World Bank.

Nigeria is one of the few newly industrialized Third World nations whose growth rate in the last two decades has been estimated to 12.8 between 1990-98 and 17.65 (1999-98) (A. de Janvry and Sadoulet, 1996). Nigeria is, however, an agrarian nation with over $56.8 \%$ of her working force engaged in farming (Afolayan, 1998). The importance of this sector in the overall economic development of Nigeria can, therefore, not be overemphasized. Doner and Kanel (1997) emphasized the significant contribution of the agricultural sector towards the overall economic development of underdeveloped countries where more than $50 \%$ of the working population is engaged in farming.

With current emphasis being laid mainly on the development of the industrial sector at the expense of agriculture, the economic development Nigeria is currently embarked upon is an inequitable one in view of its social disarticulation. To correct this, the agricultural sector has to be developed. This can only take place, however, through an agrarian reform which can be achieved through a workable land reform strategy. This paper, therefore, focuses on some economic implications of two possible land reform techniques: land consolidation against small holdings. 
Nigeria is a highly heterogeneous society in terms of the social and cultural relations of its people to land, and much detailed research would be needed in order to arrive at possible land reform strategies for the different parts of the country. This means that one set of land reform policy may not be ideal for Nigeria.

Main objectives:

1. Brief outline of the present land tenure system in two geographical divisions of Nigeria, and the rationale for land reform.

2. Identification and description of the two types of land reform strategies.

3. Economic implications of the different strategies.

4. Landowner's decisions to allocate land to forest and agriculture

\section{PRESENT LAND TENURE/ LAND USE IN THE DIFFERENT PARTS OF NIGERIA AND RATIONALE FOR LAND REFORM}

Nigeria could be divided into two broad geographical units- north and south- with respect to both the land tenure and land use patterns. With respect to this, works of Straus (1994), Famoriyo (1996), Hill (1986), Timmons (1994), Chubb (1995), and Oyenuga (1997), just to mention a few, have described to some extend the various land tenure and land use systems in Nigeria. The overall religious, cultural and social impact of the land tenure system is reflected in Table 1, which shows the apparent difference between farm sizes in the different parts of the country- the holdings of the northern part of the country being definitely larger than those of the south. This trend perhaps explains the greater proportion of unemployment among the northerners since, as a result of the past trends, a greater proportion of the working population has been turned into landless peasants due to the land tenure system (Baldwin 1996).

Table 2 shows number of farms by tenure pattern expressed as percentage of total number of farms covered by states. The significant difference in the proportion of total number of farms under family ownership are now fragmented, a greater amount of farms under family ownership still exist as large chunks since, by virtue of the customary law, the right to the land belongs to the family, as a whole. We can, therefore, identify two major sizes of farmlands, which must be taken into cognizance in the land reform strategy to be adopted.

\section{RATIONALE FOR LAND REFORM IN NIGERIA}

Much of the arguments against fragmentation which includes reduction of farm sizes, loss of land through fencing, waste of time in commuting, inadequate attention to distant fields and mechanization difficulties which all lead to low or decreased agricultural productivity have been discussed by several authors (e.g., Chisholm, op cit .; Floyd, op cit., Igbozurike 1997). Compounding the problem in Nigeria, however, is the fact that:

1. Nigeria has a large and mainly agricultural population that is rapidly increasing at about $5.8 \%$ (Afolayan 1998).

2. Nigeria has been experiencing a continuing decrease in both the aggregate size of farmed space and the proportion of persons able and willing to engage in agriculture.

3. Nigeria has recorded little success in diverse agrarian development schemes, including provision of agricultural loans/ credit to farmers, institution of large-scale farm settlement projects, establishment of agricultural development corporations and provision for technical assistance to farmers. 
Table 1

Acres Farmed By Size In Nigeria Percentage Of All Farmers

\begin{tabular}{cccccccccc}
\hline $\begin{array}{c}\text { Size of Farms } \\
\text { (Acres) }\end{array}$ & $\begin{array}{c}\text { North } \\
\text { eastern } \\
\text { States }\end{array}$ & $\begin{array}{c}\text { South } \\
\text { western } \\
\text { States }\end{array}$ & $\begin{array}{c}\text { Middle } \\
\text { Belt } \\
\text { States }\end{array}$ & $\begin{array}{c}\text { Eastern } \\
\text { States }\end{array}$ & $\begin{array}{c}\text { North } \\
\text { western } \\
\text { States }\end{array}$ & $\begin{array}{c}\text { Niger- } \\
\text { Delta } \\
\text { States }\end{array}$ & $\begin{array}{c}\text { South } \\
\text { eastern } \\
\text { States }\end{array}$ & $\begin{array}{c}\text { North } \\
\text { central } \\
\text { States }\end{array}$ \\
\hline Under 0.25 & 1.1 & 8.6 & 16.9 & 16.9 & 1.2 & 10.6 & 7.1 & 1.3 \\
Under 0.50 & 2.3 & 13.7 & 17.4 & 22.3 & 3.7 & 16.4 & 14 & 2.4 \\
Under 1.00 & 8.4 & 22.7 & 22.7 & 22.6 & 8 & 20.9 & 22.4 & 7.6 \\
Under 2.50 & 26 & 28.5 & 31.8 & 21.6 & 25.1 & 34 & 38 & 29.6 \\
Under 5.00 & 30.5 & 18.9 & 10.4 & 7.4 & 29.9 & 12. & 16.3 & 31 \\
Under 10.00 & 22.8 & 6.1 & 0.8 & 1.5 & 22.7 & 4.7 & 1.9 & 20.8 \\
Over & 8.9 & 1.4 & - & 0.5 & 9.4 & 9.5 & 0.2 & 7.3 \\
\hline
\end{tabular}

Source: Federal Office of Statistics, Economic Indicators, Vol. 6, No.8 August 1970.n.a $\equiv$ not available

Table 2

Number Of Farms By Tenure Pattern Expressed As Percentage Of Total Number Of Farms By States, 1999-2001

\begin{tabular}{ccccccccc}
\hline Selected States & $\begin{array}{c}\text { Village } \\
\text { Head }\end{array}$ & $\begin{array}{c}\text { Family } \\
\text { Head }\end{array}$ & $\begin{array}{c}\text { Inheritanc } \\
\mathrm{e}\end{array}$ & Purchase & Loan & Rent & Gift & Other \\
\hline Kaduna & 3.30 & -60.91 & -6.10 & 12.96 & 2.28 & 4.56 & 1.78 & 8.38 \\
Gongola,,Bauchi, & 7.48 & 58.27 & 7.48 & 5.12 & - & - & 1.18 & 20.47 \\
Borno & 8.33 & 65.44 & - & 13.24 & 2.45 & 2.20 & 2.70 & 5.64 \\
Niger \& Sokoto & 0.27 & 64.66 & 8.77 & 77.67 & 3.56 & 9.50 & 5.21 & 0.27 \\
Benue \& Plateau & 2.22 & 59.83 & 12.47 & - & - & 3.60 & 0.55 & 8.86 \\
Kano & 11.33 & 48.67 & 12.00 & 0.67 & 9.33 & - & 3.33 & 14.67 \\
Kwara & 7.67 & 49.14 & 17.93 & 1.84 & 5.72 & 1.60 & 4.00 & 12.10 \\
Oyo, Ondo, \& & 5.38 & 42.30 & 35.98 & 6.70 & - & 6.05 & - & 3.59 \\
Ogun & 0.59 & 61.31 & 2.23 & 16.74 & - & 18.15 & 0.30 & 0.70 \\
Imo \& Anambra & 20.60 & 54.15 & 1.33 & 8.31 & - & 13.95 & 0.33 & 1.33 \\
Cross River & 0.50 & 52.06 & 33.79 & 6.09 & - & 4.32 & 0.49 & 2.75 \\
Rivers & - & 39.01 & 23.77 & - & - & 31.84 & 2.24 & 3.14 \\
Bendel & 5.26 & 53.63 & 16.24 & 7.75 & 1.70 & 6.95 & 1.68 & 6.77 \\
Lagos & & & & & & & &
\end{tabular}

Note: Nil

Source: Rural Economic Survey of Nigeria, Federal Office of Statistics, Lagos Nigeria. 1999.

\section{POSSIBLE LAND REFORM STRATEGIES}

Two major schools of thought seem to have emerged on the issue of land reform under a setting such as Nigeria's:

1. advocates of land consolidation;

2. advocates of small farm holdings.

\section{Land Consolidation}

This is essentially a process in which scattered agricultural land holdings are amalgamated into operationally larger entities in order to eliminate some of the ills of land fragmentation (Igbozurike 1997).

This could be achieved through four basic modes (Igbozurike 1997) compromising of three basic types and a fourth category combining some aspects of the basic types. Briefly, the three basic forms are: 
Mode I

Spontaneous or Voluntary Type: in which landholders, with or without the benefit of prior exposure to propaganda, or formal education on the subject decide to amalgamate and/ or exchange their plots. This, according to Chubb (1996), is usually a small-scale merger executed without much fanfare. Such exchanges are now, however, not very common among the Igbos as earlier on reported by Chubb (Igbozurike 1997).

Mode II

Exhortative or Persuasional Type: This involves a lot of formal campaigning mounted by the government or agency charged with that responsibility, and necessarily precedes acceptance and trial on the part of landholders. Though this has not been tried extensively in Nigeria, Oluwasanmi, et. al. (1996) emphasized that there is scarcely any basis for anticipating that alone and under its best guise, more than very restricted, local and sporadic success on consolidation can be attained, as was achieved in Uboma in Imo State (Anthanio and Ijere, 1997).

\section{Mode III}

Coercive or Compulsory Type: wherein legal, police, or military tactics are employed to affect land consolidation or according to Igbozurike (1997), where in the train of a major political crisis or socioeconomic upheaval, advantage is taken of unsettled social conditions to push through consolidation measure.

The Egyptian land consolidation efforts (Saab 1997), is a fair illustration of benign official arm-twisting. So also is the Kenyan consolidation, which was coincidental with the Mau Mau rebellion (Sorrenson, 1997). In normal times, however, this mode of consolidation can be fuel for sociopolitical chaos (Penn 1961), as it involves public interest in private property. This approach was tried in Nigeria by the military government through the enactment of the land use decree of 1978. * In the Nigerian case, however, it was a complete failure in that the land use decree was enacted without full consideration of its goals, how it could be achieved, and the sociocultural constraints it was likely to encounter and how to combat it.

Therefore, even though some writers hold the strong opinion that the military could execute land reform in view of their having handled highly sensitive issues like the creation of states, the adjustment of internal boundaries and such feats which are quite inconceivable in a civilian era (Igbozurike, 1997), the attempt at land reform failed. This perhaps indicates that the issue of land reform is not as easy as it is usually perceived.

\section{Development Of Small Holdings}

The process of individualization, in itself, has been described as an indicator of agricultural development based on the fact that land becomes valuable in terms of money (Jacoby, 1995). Proponents of this approach hold that a feasible means of achieving the joint objectives of agricultural production, growth and rural equity is through two different policies:

1. Land reform, redistributing land from existing large farms into new small-scale family farms.

2. Channeling of improved inputs and credit to existing small-farm sectors in countries where land redistribution is not a feasible option in political terms (Berry and Cline, 1998).

Measures aimed at redistribution of land consist of three distinct phases: expropriation distribution and organization of new farms. The actual measures of land redistribution will depend on whether the reform only aims at changing the status of tenant cultivators to owners without otherwise affecting the pattern of land distribution and utilization, or at breaking down centrally operated estates in order to introduce new groups of cultivators.

Both policies are applicable in Nigeria where farm holdings range between 1-2 ha among the small farmers (Oyenuga, 1997) and well over 50 ha in family holdings for rich farmers. It has, therefore, been suggested that a possible approach to the present fall in productivity is to redistribute unutilized large family/ community holdings to 
members of the family who are interested in agriculture, even if it would be on a lease basis and that new technology in the form of high yielding varieties of crops should be introduced on small farms to boost their productivity.

These are the two major possible strategies towards land reform, which have been suggested for developing agrarian countries like Nigeria. Having described what each policy is all about, I shall now consider the economic implication of both approaches with the hope of identifying which would best suit the Nigerian aspiration of successful agricultural production, as well as improve rural employment and equitable income distribution.

\section{ECONOMIC IMPLICATIONS- LAND CONSOLIDATION VERSUS SMALL FARM UNITS}

According to Igbozurike (1997), fragmentation, which may be conceptually generalized as a circumstance in which one man owns or works two or more landholdings, has many casual and operational variations, which can be analyzed through the Relative Index of Land Parcellization, Pi. This is a quantitative measure of land fragmentation based on two parameters. To compute this index of spatial discontinuity, the following equation is resolved:

$p_{i}=(1 / s) /\left(D_{t} / 100\right)$

where $D_{t}=$ aggregate distance between a man's land parcels, $s=$ hectarage of each parcel (=s the mean hectarage). Where the holding is not fragmented, $\mathrm{Pi}=0$. The distance between plots has been found to be as long as 12 kilometers in some cases, necessitating that farmers ride bicycles for the long distance. There is, however, a strong argument as to the waste of time spent commuting between the parcels and the possibility of inadequate attention being paid to distant fields.

With the rapid industrial development, opportunities for non-farm employment increase. It is, therefore, believed that, if land is either redistributed or not consolidated, uneconomic size of farm units may result, especially in view of the apparent drift from the rural to urban areas.

Labor productivity increases on larger farms due to the mechanization and labor-saving techniques which result in corresponding higher operator incomes, i.e., higher returns to the managerial and labor contributions of the farm operator and his family. This, therefore, makes larger farms more profitable than small ones.

Lewis (1996) emphasized that, in an economy such as Nigeria's with a surplus supply of labor, there are large sectors of the economy where the marginal productivity of labor is negligible, zero, or even negative. This existence of "disguised" unemployment in the agricultural sector, in which the size of the family holding is so small that if some members of the family obtained employment somewhere else, the remaining members could cultivate the holding just as well, working a bit harder, is a glaring example. The ability of farmers with large extensions of land and the entrepreneurial talent to employ such labor force more gainfully is another argument in favor of land consolidation.

Most of the agricultural equipment now being manufactured in the developed countries of the world, except in Japan, is designed to work on large farms. Aside from this, land purchase sometimes involves medium or long-term loans and, because large operators have better ratings than small farmers, the interest and maturity terms will be more favorable for large farmers, making the real price of land lower for them than for small farmers. Even special government credit programs or machinery import subsidy programs channel capital disproportionately to the large farms.

Those who now control larger units of land obviously are able to influence the political processes to a large degree. That is greatly disproportionate to their numbers because of the power of their wealth. Thus, land redistribution world change this political power structure and could, therefore, lead to considerable conflicts and social unrest. The ability of all the small farmers who are given the land to cultivate to its optimum capability in suspect and could lead to loss of capital. Since large units are even normally based on large owned units, the chances of encouraging large owners to rent their land out in small parcels are extremely limited. In fact, what the Nigerian Land Use Decree did was to encourage large owners to displace tenants and operate the land on their own. 
Land consolidation would be a major innovator for most sections of rural Nigeria, regions where only a few communities have amenities such as electricity, pipe-borne water, good roads, or hospitals. Occasionally, their nonprovision is premised on the observation the people to be served are ruralities who live or work bits and pieces of fields scattered throughout the countryside and that is will be impossible to serve all these scattered locations, In this way, it might be possible to combine land consolidation and economic development in the rural areas of Nigeria at the same time.

So far, emphasis has been placed on the smallness of farm sizes being a bottleneck in Nigerian agriculture and land consolidation, hence, being a logical solution. As concerns small farm sizes, however, it should be noted that at least from an analytical viewpoint, a significantly increasing number of people argue in its favor. This includes authors such as Berry and Cline (1998), Doner and Kanel (1997) to mention a few. Most of the authors base their argument on empirical studies carried out in developing countries ranging from India to Mexico and Bolivia. The land use problem, i.e., land fragmentation, high agricultural population, etc., typical of Nigeria are also present in their study areas. Their remarks would, therefore, be applicable to a great extent under the Nigerian situation.

\section{SMALL FARM SIZE HOLDINGS}

Although labor must move from agriculture to industry in the process of development, with more than $50 \%$ of Nigeria's working labor force engaged in farming and with rapid population growth, the problem becomes that of releasing too many laborers from the agricultural sector too soon. It, therefore, follows that whatever agricultural development program is carried out needs a labor-intensive and capital-saving approach- at least in the earlier phases which could be followed by a capital-intensive, labor-saving approach in the later phases. This according to Johnston and Mellor (1961) produces both the required increase in agricultural production without displacing labor prematurely form agriculture. The fact that development in manufacturing is capital intensive/labor extensive further complicates the issue.

If the obvious assumption of land consolidation is that, in addition to receiving a contiguous holding, each person receives a plot of land, which does not fall below a defined economic threshold size, land consolidation will result in fewer landholders and landlessness would be a problem. The magnitude of such a problem can be realized in view of the inalienable birthright, high social status, and economic power associated with landholding.

With the general scarcity of capital, lack of technical know how, and abundance of relatively cheap labor, large farms follow the same pattern of agricultural operations as the small ones. Therefore, it has been argued that return to scale in this kind of situation will be approximately constant and, therefore, neutral with respect to the more general issue of farm size as related to productivity (Berry and Cline, 1998). Apart from this, decreasing returns to scale is actually possible in agricultural production since, on a small farm, the principal workers are the owner, himself, and his family and they will have a much more motivated labor force than the larger farms using hired labor.

An argument sometimes in favor of land consolidation is the ability to those farms to employ more labor. Apart from the argument earlier put forth as to the decline in labor productivity due to lack of sufficient motivation, abundant labor supply may not always be cheap labor. The recent increase in the daily wage in Nigeria from about $\$ 2.25$ to about $\$ 6.75$ (an increase of 30\%) makes the cost of labor now relatively high, while its management on a labor-intensive enterprise becomes very difficult due to their lack of skill. In view of this, owners of large farms sometimes prefer capital-intensive, mechanized operations with relatively small force of skilled workers.

With the present set-up in which some few families or individuals hold very large estates for prestige purposes or for asset placement rather than for full agricultural production, output on the farms tends to be below its maximum potential level because of under-use of land. This is especially true in the prevailing circumstances of high inflation, which makes landholding for speculative gain attractive. Agrarian reform, in this case, redistributing large estates into new family farms of a moderate size, can combine under-used land with the surplus labor and raise agricultural production. This potential increase in production may be sufficient to allow a substantial use on the incomes of rural poor even if they have to pay compensation to former landowners in the form of some tariff. In this case, the greater employment capacity of small farm units is also demonstrated. 
Georgescu-Roegan (1990) cautioned that small farm agriculture of peasant proprietors may lead to an access of capital equipment on smallholdings. However, the possibility of technological research directed to achieve equipment adapted to fit small farm, as was done in Japan (Doner, 1992), or the reorganization of large farms systems on cooperative principles can be designed to assure both labor absorption and efficiency in the use of capital.

Another argument put forth as being the cause of higher utilization of available land resources on small farms than on large ones is that of labor market-dualism. The economies of most developing countries are characterized by the co-existence of both the "modern" and "traditional" sectors. Whereas, the former is relatively highly capitalized, i.e., using labor until its marginal product equals the modern sector wage rate, the latter, with its abundant labor supply, has a relatively lower marginal product, possibly below the income received (Booth and Sundrum (1996). This same dualism occurs in agriculture and causes distortion in the sector's utilization of available land and labor resources.

Several factors cause different marginal productivity of labor across farm sizes:

1. Tendency of income sharing on smaller family farms. If the marginal product of labor is low on this farm, labor supply price from such a family will be low since this price would be close to the average product of labor on the small farm. Since marginal product in the large farm sector will not be below the wage rate, which, in turn, equals the wage rate, it follows that the marginal product of labor in the larger farm will be greater than on smaller ones. Therefore, the effective price of family labor on the small farm is lower than the effective price on large farms.

2. Where family decision making is possible, the family would hire out labor until its marginal product on the family farm rose to equal the wage obtainable outside after allowing for transportation cost to the alternative site and any preferences to have or not to have family members working on the farm. These latter factors further contribute to a lower marginal product of labor on the family farm compared to the wage rate somewhere else.

3. Where large landowners have monophony power in the labor market, they may hire less and, hence, produce less on the same piece of land than would several competitive small farmers.

Therefore, it follows that since the effective price of labor is lower on the small farm, which as a result can exploit more marginal land and bring a larger share of its land under cultivation, output per unit of available land resources is increased. As such, labor market dualism leads to higher utilization of the available land resource on small farms than on large ones.

The ability of the families to consume a greater proportion of their output reduces the risks associated with unfavorable prices and encourages increased productivity on smaller farms. Apart from this, if the large landowner maintains a monopoly on the product market, there is a great tendency for him to reduce production in order to avoid driving down the prices. The small farmers, on the other hand, would not since they would be competitive among each other. This invariably reduces the relative productivity of larger farms when measured at fixed prices.

In a developing country like Nigeria, availability of market access roads is limited. This means that for larger farms, not all the area would be easily accessible both for cultivation and transportation of primary products, The result is reduced productivity on such lands, whereas, such land area would be fully utilized by several farmers as most of them would not mind commuting on their bicycles to farms as far as 12 millimeters or even more (Igbozurike, 1997) from their homes. The possibility of differences in the land quality on the large area and the inability of the larger farmer to effectively cultivate all, especially the marginal land is of importance. Here, small farmers, through diverse production techniques, could be able to handle all land areas.

With abundant labor supply, the systematic shift towards heavy use of land and capital, as consequential to land consolidation and mechanization, imply a general decline in total factor productivity, as the cheap factor of production labor is under-utilized. Therefore, if the goal of the economy is maximization of the economy's total output, as well as equitable distribution of income and employment opportunities, small farm holdings better achieve these goals given their high labor absorption and the low incomes of most of the persons who live on them. 
State or cooperative farms, unless correctly organized, may fall below private family farms in productive potential (Cline and Berry, 1998). This is mainly due to the general absence of increasing returns to scale as earlier mentioned.

\section{SUMMARY}

From the above discussion, it is apparent that agrarian structures with unequal land distribution should be expected to lead to underutilization of land and, therefore, low land productivity on large farms. It could also be conceded that small farm holdings' system of agricultural reforms has the advantage of provision of more employment, more equitable income distribution, a wider and more relevant demand structure for the growing manufacturing sector, a better base for farm financed welfare, and more rational investment policies in both the agricultural and nonagricultural sectors of the economy.

On the other hand, proponents of land consolidation argue against small farm holdings on the basis of:

1. the uneconomic farm sizes currently associated with the present traditional land tenure system;

2. the inability of the small farmers to attract loans and credit both from the government and banks to aid agricultural development;

3. the question of the distance between farms and its effect on productivity;

4. inability of the urban-industrial sector to employ individuals displaced from agriculture as a result of uneconomic farm sizes;

5. inevitable irregularities and land-grabbing which redistribution and registration of titles might occasion;

6. the distributional impact- increasing opportunity for some and decreasing it for others- decrease in security for virtually all farmers.

\section{POLICY SUGGESTIONS}

\section{Peasant Awareness}

It is clear that the first step needed is to educate the peasants about the reform objectives, laws and procedures. This is necessary for eliciting the support and cooperation of the peasantry. Peasant's support would help resist attempts to foil the reform. It might be useful if local peasant associations are formed and peasants are involved in the process of strategy that is more progressive and capable of accommodating the interests promoting participation and cooperation among farmers on an independent and the local government who are closer to the peasants. Such a weak relationship should be strengthened.

\section{Econometric Models of Land Use}

Land use share models have been widely analyzed in the past decade (Lichtenberg, Stavins and Jaffe, Parks and Kramer, Wu and Sereston, Plantinga 1996, Hardie and Parks, Miller and Plantinga). Following Miller and Plantiga, we aggregate the optimal allocations by individual landowners to derive the observed share of land in county $i$ in use $k$ in time $t$, denoted $y_{k}(t, i)$. The observed shares are an additive function of the expected share $\left(p_{\mathrm{k}}(\mathrm{t}, \mathrm{i})\right)$ and a composite error term related to sampling errors and exogenous shocks affecting land use allocations $\left(\varepsilon_{\mathrm{k}}(\mathrm{t}, \mathrm{i})\right)$. The expected land use shares are a function of county-level economic decision and land-quality variables $(X(t, i))$. We specify:

$$
p_{k}(t, 1)=\frac{e^{B_{k}^{\prime} X(t, i)}}{\sum_{s=1}^{K} e^{B_{s}^{\prime} X(t, i)}} .
$$

for $k=1, \ldots, k$ where $\beta_{k}$ is a vector of unobserved parameters. The logistic specification restricts the expected shares to the unit interval and ensures that they sum to one. As well, the logarithm of the observed shares normalized $y_{\mathrm{k}}(\mathrm{t}, \mathrm{i})$ yields 
$\ln y_{k}(t, i) / y_{1}(t, i)=\beta_{k}^{\prime} x(t, i)-\beta_{1}^{\prime} x(t, i)$

for $k=2, \ldots, k$. The model is identified if we normalize the parameters by setting $\beta_{1}=0$ and can be estimated by least squares provided the number of observations exceeds the number of unknown parameters in $\beta_{k .}$.

\section{Estimation Results For Three Nigeria States}

We estimate land use share models for Eastern States, Western States, and Northern States. These states represent a broad range of current land use patterns, physiographic conditions, and apparent opportunities for afforestation. East is heavily forested and, thus, has little agricultural land available for conversion. We focus on the North since much of the land in northern Nigeria is publicly owned and little is in agricultural use. Private forest and agricultural land account for between $80 \%$ and $93 \%$ of the total land area in the three study areas. We assemble county data on land areas at different points in time and, normalizing on total land area, form land use shares $\mathrm{y}_{\mathrm{k}}(\mathrm{i}, \mathrm{t})$, where $\mathrm{k}$ indexes forest $(\mathrm{k}=1)$ and agricultural $(\mathrm{k}=2)$ uses and $\mathrm{i}$ and $\mathrm{t}$ index counties and time, respectively. Total land area equals the area of all land in the county, except publicly owned forest, and major parklands. We assume that the area of land in these uses is exogenous to our model. The use of cross-sectional data is required because we have limited time-series information on forest area. A third category (urban/other land) is defined as all land not classified as private forest, agricultural land, and publicly owned forest and parks (i.e., $\mathrm{y}_{3}(\mathrm{i}, \mathrm{t})=1-\mathrm{y}_{1}(\mathrm{i}, \mathrm{t})-\mathrm{y}_{2}(\mathrm{i}, \mathrm{t})$ ). This category includes developed land in urban, suburban, and rural areas, and other unclassified land. We measure rents from forestry $\left(\mathrm{R}_{1}(\mathrm{i}, \mathrm{t})\right)$ as the present discounted value of a stream of real timber revenues per acre. we use population density $(\mathrm{PD}(\mathrm{i}, \mathrm{t}))$ to explain the share of land devoted to urban/other uses. We include measures of the average Land Capability Class (LCC) rating (O1(i)) and the percentage of total land in LCC I and II ( $\left.\mathrm{Q}_{2}(\mathrm{i})\right)$. In the three models, we include a constant term $($ ) and intercept shifters $(\mathrm{D}(\mathrm{t}))$ for each time period except the last. In the East model, we include a variable (TT(i)) measuring the travel time. For each state, we estimate models with $\ln \left(\gamma_{2} / \gamma_{1}\right)$ and $\ln \left(\gamma_{3} / \gamma_{1}\right)$ specified as linear functions of the independent variables. Given that the logistic transformation (1) is used largely due to convenience, we conduct Ramsey's RESET test (Davidson and MacKinnon, 2000) to evaluate the log-linear specification (2). In all cases we fail to reject the null hypothesis of linearity at the 5\% level.

To a large degree, the empirical results conform to prior expectations (table 3). The estimated coefficients can be interpreted as the percentage change in the share ratio $\left(\mathrm{y}_{\mathrm{k}} / \mathrm{y}_{1}\right)$ for a one-unit change in the independent variable. In the $\ln \left(\mathrm{y}_{2} / \mathrm{y}_{1}\right)$ equations, the coefficients on forest and agricultural rents are negative and positive, respectively and all except one are significantly different from zero at the 5\% level. All else equal an increase in the forest rent decreases the share of agricultural land relative to the forest share. An increase in the agricultural rent has the opposite effect. In the $\ln \left(\mathrm{y}_{3} / \mathrm{y}_{1)}\right.$ equations, the forest rent coefficients are negative, as expected, but none are significantly different from zero. This is a plausible result since forest rents are unlikely to influence the allocation of land to urban and other uses. The effect of agricultural rents on the urban/other to forest ratio are ambiguous a priori, and most of the estimated coefficients are not significantly different from zero.

As expected the coefficients on population density are positive in the $\ln \left(\mathrm{y}_{3} / \mathrm{y}_{1}\right)$ equations and all are significantly different from zero at the 5\% level. Population density does not have a significant effect on the ratio of agricultural to forest land. Counties with higher average LCC ratings $\left(\mathrm{Q}_{1}\right)$, corresponding to lower average land quality, tend to have less agricultural land relative to forest and (i.e., lower values of $\left(\mathrm{y}_{2} / \mathrm{y}_{1}\right)$. Conversely, counties with larger shares of high-quality agricultural land $\left(\mathrm{Q}_{2}\right)$ tend to have higher agricultural to forest share ratios, though the coefficients on $\mathrm{Q}_{2}$ are not significantly different from zero in the East and North models. The effects of $\mathrm{Q}_{1}$ and $\mathrm{Q}_{2}$ on $\ln \left(\mathrm{y}_{3} / \mathrm{y}_{1}\right)$ are ambiguous a priori and many of the coefficients are not significantly different from zero. Finally, counties in the East with higher transportation costs tend to have less agricultural land relative to forest. 
Table 3. Estimation Results for Land Use Share Models

\begin{tabular}{|c|c|c|c|c|c|c|}
\hline \multirow[b]{2}{*}{$\begin{array}{c}\text { Parameter } \\
\text { Rents }\end{array}$} & \multicolumn{2}{|c|}{ Eastern States } & \multicolumn{2}{|c|}{ Western States } & \multicolumn{2}{|c|}{ Northern States } \\
\hline & $\ln \left(\mathrm{y}_{2} / \mathrm{y}_{1}\right)$ & $\ln \left(\mathrm{y}_{3} / \mathrm{y}_{1}\right)$ & $\ln \left(\mathrm{y}_{2} / \mathrm{y}_{1}\right)$ & $\ln \left(\mathrm{y}_{3} / \mathrm{y}_{1}\right)$ & $\ln \left(\mathrm{y}_{2} / \mathrm{y}_{1}\right)$ & $\ln \left(\mathrm{y}_{2} / \mathrm{y}_{1}\right)$ \\
\hline \multirow[t]{2}{*}{$\mathrm{R}_{1}$} & 0.05 & -0.03 & -0.01 & -0.0003 & -0.02 & -0.02 \\
\hline & -1.65 & 1.43 & -6.7 & -0.27 & -3.5 & -1.21 \\
\hline \multirow[t]{2}{*}{$\mathrm{R}_{2}$} & 0.0005 & -0.0003 & 0.001 & 0.0004 & 0.001 & 0.0002 \\
\hline & 2.68 & -0.257 & -5.14 & 1.35 & 5.27 & 1.82 \\
\hline \multicolumn{7}{|l|}{ Other } \\
\hline \multirow[t]{2}{*}{ PD } & 2 & 0.002 & -0.027 & 2.66 & 0.06 & 1.89 \\
\hline & 0.97 & 1.81 & -0.7 & 7.05 & 0.18 & 5.48 \\
\hline \multirow[t]{2}{*}{$\mathrm{C}$} & 1.37 & 0.42 & -0.98 & -1.49 & 0.29 & 3.96 \\
\hline & 0.96 & 0.38 & -1.19 & -1.87 & 0.27 & 3.2 \\
\hline \multirow[t]{2}{*}{$\mathrm{D}(71)$} & -0.09 & -0.04 & & & & \\
\hline & -0.42 & -0.25 & & & & \\
\hline \multirow[t]{2}{*}{$\mathrm{D}(81)$} & 0.2 & -0.09 & & & & \\
\hline & 1.3 & -0.67 & & & & \\
\hline \multirow[t]{2}{*}{$\mathrm{D}(82)$} & & & & & 0.15 & -0.03 \\
\hline & & & & & 1.5 & -0.29 \\
\hline \multirow[t]{2}{*}{$\mathrm{D}(83)$} & & & 0.21 & 0.09 & & \\
\hline & & & 2.1 & 0.94 & & \\
\hline \multirow[t]{2}{*}{ TT } & -0.2 & -0.02 & & & & \\
\hline & -1.99 & -0.21 & & & & \\
\hline \multirow{2}{*}{\multicolumn{7}{|c|}{$\begin{array}{c}\text { Land } \\
\text { Quality }\end{array}$}} \\
\hline & & & & & & \\
\hline \multirow[t]{2}{*}{$\mathrm{Q}_{1}$} & -0.74 & -0.29 & -0.15 & -0.01 & -0.47 & 1.09 \\
\hline & -3.67 & -1.78 & -1.02 & -0.05 & -2.5 & -5.12 \\
\hline \multirow[t]{2}{*}{$\mathrm{Q}_{2}$} & 2.18 & 1.73 & 1.25 & -1.08 & 0.54 & -1.53 \\
\hline & 0.9 & 0.88 & 2.72 & -1.52 & 0.77 & -1.92 \\
\hline \multirow[t]{2}{*}{$\mathrm{R}^{2}$} & 0.8 & 0.61 & 0.55 & 0.44 & 0.72 & 0.72 \\
\hline & 0.8 & 0.61 & 0.55 & 0.44 & 0.72 & 0.72 \\
\hline
\end{tabular}

\section{CONCLUSION}

Traditional land tenure system defined the opportunity to earn income in farming and provided the security that an individual would always have access to some part of his family's land.

Past changes in the physical and economic environment had the tenure system changed to allow for investment in land and transfer of land to those in a position to use the land more productively the establishment of cocoa plantations in the old Western Region of Nigeria posed little problem (Oni, 1997). However, these changes have gone far enough to effect overall improved productivity on land. Therefore, investment in land improvement and increases on productivity are hindered by tenure rules.

Some have suggested land consolidation as a way out, while others have suggested individualization as a solution. However, the cost, as well as the benefits of such policies must be considered before either is chosen as the solution.

While the odds appear to be in favor of small holdings as a result of its many benefits, which include increase in agricultural investment, increased land mobility and productivity, among others, some likely costs of individualization, which include social disorganization, disruption of tribal societies, loss of economic security for some large holders, and severe distributional impacts with respect to landholdings and employment, among others, as earlier discussed, must be critically looked into. approaches:

According to Jacoby (1997), land consolidation programs can be carried out fewer than three distinct 
1. Consolidation of fragmented holdings without any construction work.

2. Consolidation of fragmented holdings with small improvements in the road system, but without major construction work.

3. Land consolidation combined with all kinds of construction work that may be connected with the reorganization of holdings.

Only type 3 can be considered an agrarian reform measure since it focuses on agricultural development in the broadest sense by combing reorganization of holding with land improvement which is a precondition for agricultural development. Under this condition, land consolidation, as a land reform policy also appears attractive and economically suitable under some prevailing conditions in Nigeria.

Finally, the unknown nature of the ultimate results of tenure changes increases the risks involved in introducing any program of land reform. This must be taken into full consideration in initiating any land reform program.

Economic justification alone, should not however, be the only basis for determining the particular land reform policy to be adopted. The goal of the State had to be defined or understood before any policy can be introduced.

Land reform is essentially an attempt by the government through public policies at inducing a change among states of the agrarian structure to increase the productivity of land as well as the welfare of the peasantry. The divergent socio-political setting in Nigeria in form of the semi feudal estates controlled by the traditional landed elite with either bonded labor or rent in labor services amongst the Hausas and the peasant farms ranging from family to subfamily (semi-proletarian) where no labor is hired but some may be sold as obtained in the Southern part should be taken into consideration.

With this peculiar setting in Nigeria it follows that while the policy of government should be directed towards improvement of the welfare of the peasants among the Northern Hausas, the policy for the South should be geared towards increased land productivity.

From the earlier discussion one could be tempted to conclude that realizing both the economic and political goal of the ruling Government land redistribution would be an ideal policy for the North while consolidation appears to be the answer for the Southern part. However, the issue at stake may not be as easily resolvable at that.

Land reforms are not economic needs for the modern sector but merely political gains of working class and peasants. Probably this is one of the reasons why the Nigerian Government has not been pressurized into instituting a workable land reform program. The fact that there is currently no strong pressure that questions the existing social order further makes the land reform issues not being considered an urgent matter.

Any program introduced in the Northern States, which opposes the semi feudal setting, is bound to face strong opposition by the landed elites. This is because these elites have a strong control of the State apparatus in form of diversified investments in industry, commerce and finance that give them economic power beyond agriculture. The problem bring faces by the Socialist oriented political parties in the North is a glaring example. This therefore means that before any meaningful change can take place, there has to be awareness by the peasants of the need for such.

Most of the large farmers in the North are now into modernization especially in view of the many irrigation schemes initiated by the Federal Government. Any drastic land redistribution is likely to nullify past productivity at least in the short run. With a high degree of urbanization and continuous rural-urban migration, this could lead to increasing food shortages resulting in higher prices, which would nullify the good effects of the land redistribution program.

With the capitalist form of government in Nigeria, transformation of the agrarian structure is becoming increasingly difficult especially in view of its possible international consequences and the increasing powers of the bourgeois. With the problems of food shortage and worsening rural poverty, it is not surprise that in an attempt to 
avoid clashes with the big landowners, some State Governments introduced the integrated rural development programs. These are programs designed to create some upper peasant classes without influencing land ownership, as technological support becomes substitutes for land redistribution.

Countries may pass laws imposing ceiling and arranging for redistribution of land in excess of these ceilings, but those who are likely to lose their land as a result generally find innumerable ways of evading in protracted litigation challenging the constitutional validity of the laws., by rearranging their property in the names of nominees, by slowing down implementation or when ultimately forced to give up any of their property, by surrendering only the least valuable parts. As a result, the record of effective implementation of land redistribution programmed in a peaceful manner has been miserable. Most research has to be carried out into the intricate socio-political setting within the country before a viable land reform program can be initiated. Ucheda (1999) rightly argued that until the government fully understands the operation of the present tenure system and its relation to agricultural viability, it is quite risky to alter the basic principles of land tenure. The failure of the 1978 Land Use Decree points towards the necessity of such a detailed study.

\section{REFERENCE}

1. Alain de Janvry, 1992. The Role of Land Reform In Economic Development: Policies and Politics. American Journal of Agric. Economics. Vol. 63, No. 2, 1981.

2. Alain de Janvry and Elizabeth Sadoulet, 1996. Social Articulation As A Conditon For Equitable Growth. Cal. Agri. Experiment Station Giannini Foundation of Agric. Econ.

3. Afolayan, A. 1998. A Geography of Nigerian Development. Heinnemann Educational Books, 1978.

4. $\quad$ Anthanio, Q.B.O and Ijere, M.O., 1997. Uboma Devlopment Project 1964-1972. An Appraisal of A Technical Assisatance Program for Rural Development In Nigeria, Shell International Petroleum Company, LTD.

5. Baldwin, Robert E. 1996. Patterns of Development In Newly Settled Regions, Manchester School of Economics \& Social Studies, Vol. 24 (May 1996).

6. Berry, R.A. and Cline, W.R. (1978). Developing Countries. The John Hopkins University Press: London.

7. Booth, A. and R.M. Sundrum, 1995. Labour Absorption In Agriculture: Theoretical Analysis and Empirical Investigations, Oxford, New York, Melbourne-University Press.

8. Chisholm, M. 1995. Rural Settlement and Land Use. London: Hutchinson University Library.

9. Chubb, L.T, 1996. Ibo Land Tenure, Ibadan University Press: Nigeria.

10. Davidson R. and J.G. McCkinnon. Estimation and inference in Econometrics. New York: Oxford University Press, 2000.

11. Doner, P. and Kanel, D., 1997. The Economic Case For Land Reform: employment, Income Distribution and Productivity. Reprint No. 74. Land Tenure Center, Univ. of Winsconsin, Madison.

12. Famoriyo, B., 1996. Land Tenure and Agricultural Development In Nigeria, Nigerian Institure of Social and economic research, Ibadan.

13. Floyd, B., 1997. agricultural Innovation In Jamacia: The Yallahs Valley Land Authority, economic Geography, Vol. 46, No. 1, pp. 63-77.

14. Georgeson-Roegen, N., 1990. Economic Theory and Agrarian economics. Oxford economic Papers (12).

15. Berry and Cline (1998) Agrarian Systems and Rural Development. Alternative Agrarian Systems and Rural Development In The Third World. Hill, p. 1996. Rural Hausa. London: Cambridge University Press.

16. Igbozurike, M.U., 1997. Land Tenure Relations, Social Relations, and The Analysis of Spatial Discontinutiy Srea, Institute of British Geographers, Vol. 6, No. 2.

17. Igbozurike, 1998. Agrarian Structures and Land Settlement, Food and Agriculture Organization, Rome.

18. Johnston, B.F. and Mellor, J.W. 1961. The Role of Agriculture In Economic Development. American Economic Review (51).

19. Land Use Decree of 1999* - Nigerian Government Press, Lagos, Nigeria, 1999.

20. Lewis, 1996. Economic Development with Unlimited Supplies of Labor: In Agrarwala and Singh 9eds), The Economics of Underdevelopment (New York : Oxford University Press, 1958) pp. 400-449.

21. Oluwasanmi, H.O., et. Al., 1996. Uboma A Socioeconomic and Nutritional Survey of A Rural Community In Eastern Nigeria. London: Geographical Publications, Ltd. 
22. Oni, P.O., 1997. Plantation Agriculture In The Western region- Lagos. Journal of Agriculture, June, 1974.

23. Oyenuga, V.A., 1997. Agriculture In Nigeria. Rome: Food and agriculture Organization.

24. Parsons, K.H., 1996. Land Reform and Agricultural Development, K.H. Parsons, K.J. Penn, and P.H. Raup (eds) Land Tenure. Madison: University of Winsconsin Press.

25. Penn, R.J., 1961. Public Interest In Private Property (Land): Land economics, Vol. 37, No. 2.

26. Saab, G.S, 1997. The Egyptian Agrarian Reform, Oxford University Press: London

27. Sorrenson, M.P.K., 1967. Land Reform In The Kikuyu Country. A Study In Government Policy. Oxford University Press, Nairobi.

28. Straus, W.W., 1994. Land Tenure Among The Rural Hausa. Madison: Land Tenure Center, University of Winsconsin.

29. Timmons, John F., 1994. Land Tenure Policy Goods, Journal of Land and Public Utility Economics, Vol. 19. pp. $165-179$.

30. Uchendu, U.C., 1999. The Conflict Between National Land Policies and Sovereignty Over Land In Tropical Africa. Paper read at the Seminar Of Problems of Land Tenure In Africa Development held at the Afrika Studies Centrum, Leiden, Holland.

31. World Bank, 1996. Land Reform-World Band Paper-Rural Development Series, Washington, D.C. 


\section{NOTES}

